Article

\title{
The Main Drivers to Face the Challenges of Increasing the Intelligence of Sanitary Sewage Systems in Brazilian Cities
}

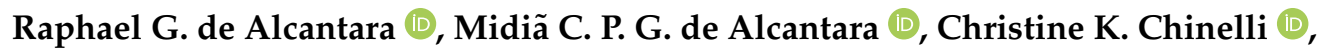 \\ Fabricio C. Dias (D), Renata L. V. Mariano (D), Orlando C. Longo (D) and Carlos A. P. Soares *(D) \\ Pós-Graduação em Engenharia Civil, Universidade Federal Fluminense, Niterói RJ 24210-240, Brazil; \\ ralcantara@id.uff.br (R.G.d.A.); mpitta@id.uff.br (M.C.P.G.d.A.); cchinelli@id.uff.br (C.K.C.); \\ fcdias@yahoo.com (F.C.D.); renatavenancioengenharia@gmail.com (R.L.V.M.); orlandolongo@id.uff.br (O.C.L.) \\ * Correspondence: capsoares@id.uff.br; Tel.: +55-21-2629-5410
}

Received: 26 October 2020; Accepted: 7 December 2020; Published: 10 December 2020

check for updates

\begin{abstract}
The sewage system is one of the components of the complex ecosystem of cities. Although increasing the intelligence of this system is an essential driver for having smarter cities, there are few works aimed at identifying drivers that enhance the intelligence of urban sanitary sewage systems. The identification of these drivers, as well as the degree of importance of each one, is strongly influenced by the perception of researchers and professionals about the reality of each country. In this work, we identified the main drivers that increase the intelligence of the Brazilian urban sanitary sewage systems based on extensive and detailed bibliographic research and in the vision of 241 Brazilian professionals with experience in the concerned field. We used factor analysis to explore the relationship between the drivers. The survey results showed that the twenty drivers found in the literature can be grouped into six factors, depending on their approach, and that seven were considered priorities. They also showed that the path to be followed to increase the intelligence of sewage systems in Brazilian cities is still influenced by the challenges of solving structural problems.
\end{abstract}

Keywords: sewage; sewer; wastewater; sanitary sewage; smart city; intelligent city

\section{Introduction}

The sewage system has aroused the interest of researchers, mainly because of its ability to impact the environment [1], quality of life [2], the health of the population [1], and the cost of public health [3]. In a context where one of humanity's most significant challenges has been the sustainable management of natural resources, smart waste management is an essential issue for societies' sustainability [4].

However, in several countries, mainly in underdeveloped and developing countries, adequate access to sewage services has been a recurring problem. The universalization of sanitation services is a concern expressed in objective 6 of the UN Agenda 2030 [5]. The reality of global sanitation is very different. While underdeveloped countries are concerned with open defecation [1], developed countries plan innovative solutions considering factors such as population growth, climate change, land use, urbanization, and changing legal requirements [6]. Between these two so distant poles are developing countries, which face the rapid growth of their cities with the mission of expanding their infrastructure and seeking more economically sustainable solutions $[7,8]$.

In Brazil, Law No. 11,445 / 07, which instituted the basic sanitation guidelines, has as one of its objectives the universalization of access to sewage services and establishes the public power as the holder of the services with an obligation to plan, regulate, execute, and inspect. However, as in most Latin American countries, noncompliance with legislation associated with factors such 
as uncontrolled urban growth and population growth makes it difficult, especially for the poorest population, to access adequate sanitation services. As it is intrinsically related to the city's urban space, sanitary sewage is also related to the form, land use, and public policy for improving and maintaining the city's services. Thus, urban sanitation must be approached as a system in which political, socioeconomic, and environmental factors that interact in the sense that technical solutions can be made viable and implemented.

As an essential city service, the evolution of the urban sanitary sewage systems must be considered in the context of the main concept currently considered for the cities evolution, that of the smart city. This concept has evolved mainly due to society's demands for more efficient and sustainable urban services and the development of new technologies, enhancing sustainability and quality of life [9]. In a survey about the main drivers that increase cities' intelligence, of the twenty drivers considered important, the infrastructure of cities (networks of rainwater, sanitation and water, and sewage services) was considered one of the seven priority drivers [10].

Studies on sanitary sewage have mainly addressed issues related to sanitation services [11], public health [1], pollution control [12,13], environmental impacts [8], population behavior [14], and water quality [15], being scarce the works aiming at the identification of the drivers that influence the increase of the urban sanitary sewage system intelligence. The identification of these drivers, as well as the degree of importance of each one, is strongly influenced by the perception of researchers and professionals about the reality of each country. In this work, we identified the main drivers that increase the intelligence of the Brazilian urban sanitary sewage systems, based on extensive and detailed bibliographic research and in the vision of 241 Brazilian professionals with experience in the concerned field.

Considering the scarcity of public resources, mainly in underdeveloped and developing countries, this work also contributes so that city managers can direct their efforts towards the formulation and financing of public policy that enhance solutions to problems that hinder the increase of the system's intelligence of sewage, including structural problems caused by the lack or inefficiency of sewage services. According to [16], for cities to increase their intelligence, structural issues must be solved.

The quality of the design of sewage networks is highly dependent on the creativity of designers in adopting methods, techniques, and processes that consider aspects related to cost, society, and the environment within the scope of local and regional peculiarities. In this context, this work also collaborates so that these professionals can direct their efforts because the main factors that increase the intelligence of sewage services can consider the local realities and, thus, increase the chances of success.

\section{Materials and Methods}

The main research question was: what are the main drivers contributing to a more intelligent sewage system in Brazilian cities? To answer this question, a four-step approach was used: bibliographic research, identification of potential drivers, a survey with expert's opinions, and data analysis.

\subsection{Identification of Potential Drivers}

We carried out extensive and detailed bibliographic research on the Web of Science, Scopus, Scielo and the main scientific publishers' websites, considering works published in the last 10 years, so that the drivers were the most representative of the current reality. We use keywords in Portuguese and English. In Portuguese we use the keywords "tratamento de esgoto," "coleta de esgoto," and "esgotamento sanitário," which were combined with "smart cities." In English, we use the keywords "sewage treatment," "sewage collection," "sanitary sewage," "wastewater," which were combined with "smart city" and "intelligent city."

We performed bibliographic research mainly following the recommendations of the Preferred Reporting Items for Systematic Reviews and Meta-Analyzes (PRISMA) [10,16]. Initially, we carried out an exploratory reading to exclude articles that did not have evidence or information on the subjects covered. Then we performed a selective reading on the selected articles, excluding those that did not 
have relevant primary information. We ended the bibliographic search when we realized that we were not finding new works with relevant information. Figure 1 summarizes the bibliographic research from the PRISMA flowchart.

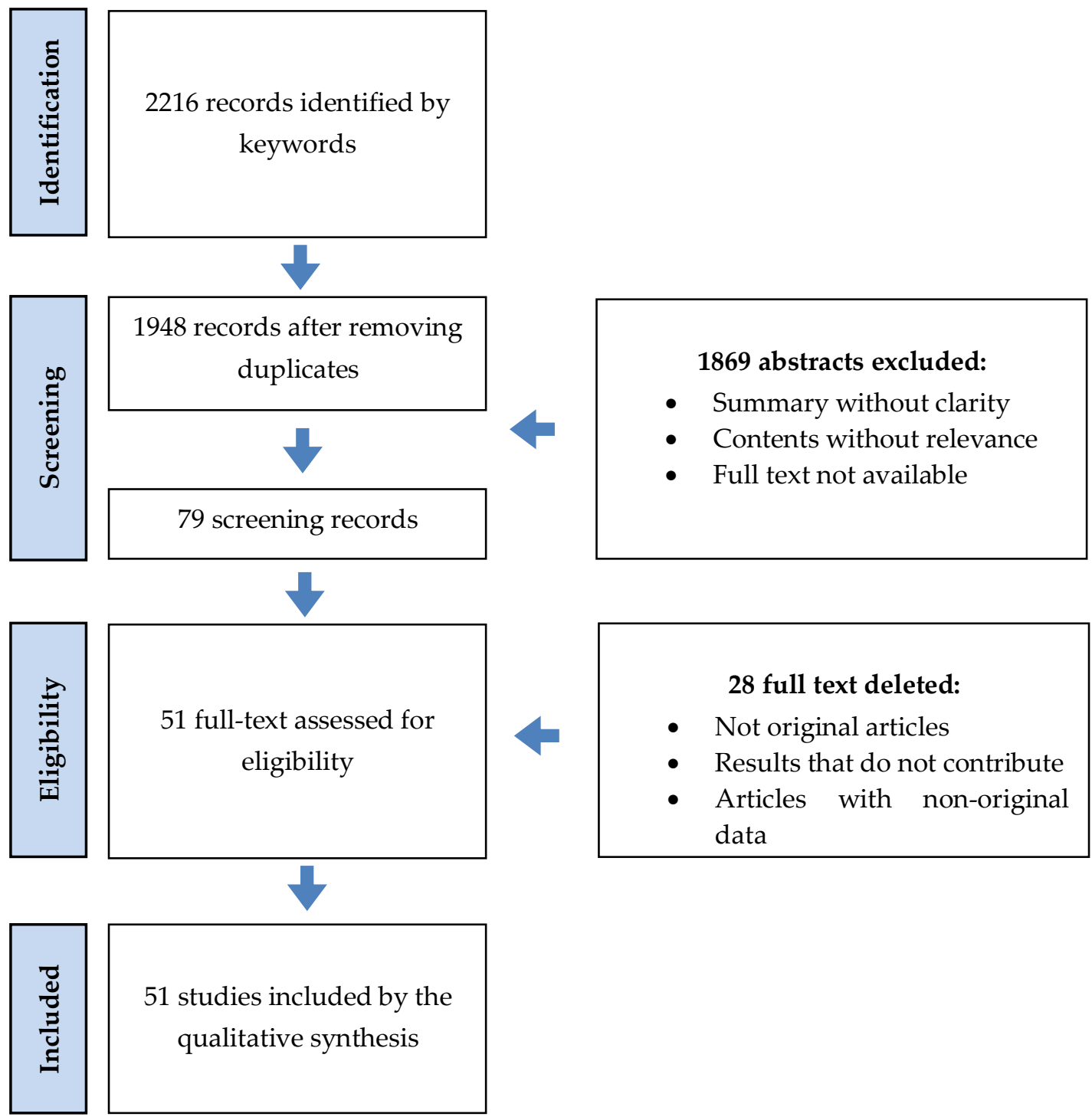

Figure 1. Synthesis of bibliographic research from the PRISMA flowchart.

For the 51 selected articles, we created a spreadsheet with all the relevant information to support the research and served as a basis for the driver's identification. During the analysis process, we consider the perspectives, multiplicity, and plurality of approaches, order and summarize the information, relate the main concepts and knowledge, and identify the drivers. We consider relevant the drivers covered in at least two works that did not reference each other, which resulted in a set of twenty drivers. We prioritize drivers based on the results of the survey of the expert's opinion.

\subsection{Survey of Expert's Opinion}

We used a questionnaire developed on an online platform (Google Forms), containing demographic questions and questions addressing the importance of the selected drivers, which were presented at random to prevent the responses from being influenced by the order they appeared. Experts used a five-point Likert scale, ranging from "extremely important" to "minimally important," to express their opinions on the importance that each driver contributes to making the urban sanitary sewage systems 
more intelligent. The preliminary version of the questionnaire was pre-tested with three specialists to identify possible doubts and eliminate inconsistencies. The revised questionnaire based on the comments received served as the basis for the survey.

We searched for professionals working in concerned fields of this research on university websites and sanitation companies, who were invited to participate in the survey by email and social networks. From May 11 to July 13, 2020, 252 professionals participated in the survey, of which 11 were excluded for not having completed the questionnaire, resulting in a sample with 241 respondents.

\subsection{Data Analysis}

To assess the reliability of the data collection instrument and the respondents, we used Cronbach's alpha $[17,18]$. For drivers' prioritization, we use the relative median concept [16], which establishes an indicator as a function of the distance from the median to the nearest class. Thus, taking Figure 2 as an example, the median equal to four in the first line is much closer to the frequency represented by the number three. In the second line, when we add more cells to the frequency represented by the number five, the median moves to the right. Although the two lines have medians equal to four, the second line driver can be interpreted as more critical since it received more ratings like five and maintained the other frequencies.

\begin{tabular}{llllllllllllllllllllllllllllll}
\hline 1 & 2 & 2 & 3 & 3 & 3 & 3 & 3 & 3 & 4 & 4 & 4 & 4 & 4 & 4 & 5 & 5 & 5 & 5 \\
\hline 1 & 2 & 2 & 3 & 3 & 3 & 3 & 3 & 3 & 4 & 4 & 4 & 4 & 4 & 4 & 5 & 5 & 5 & 5 & 5 & 5 & 5 & 5 & 5 & 5 & 5 & 5 & 5 & 5 \\
\hline
\end{tabular}

Figure 2. Example of the median position [16].

The formula used to calculate the relative medians was

$$
R m=\left\{\begin{array}{cc}
1+\frac{P_{r}}{j_{1}} & \text { for } m=1 \\
m+\frac{P_{r}-\left(\sum_{\dot{i}=1}^{m-1} j_{i}+1\right)}{j_{m}} & \text { for } 2 \leq \mathrm{m} \leq \mathrm{N} \text { and } \mathrm{m}=\text { integer } \\
\mathrm{m}+5 & \text { for } 1 \leq \mathrm{m} \leq \mathrm{N} \text { and } \mathrm{m}=\text { fractional number } \\
\mathrm{N} & \text { for } \mathrm{m}=\mathrm{N}
\end{array}\right\}
$$

where $\mathrm{Rm}$ is the relative median, $\mathrm{m}$ is the median, $\mathrm{Pr}$ is the median position, $\mathrm{N}$ is the number of respondents, and $\mathrm{ji}$ is the number of respondents who have been assigned the semantic classification of "i."

The results were grouped considering the three colleges of knowledge organized by the Coordination for the Improvement of Higher Education Personnel (CAPES), Brazil, which group the training areas according to the affinity of their objects, cognitive methods, and instrumental resources. The colleges are Humanities Sciences, which covers areas such as architecture and urbanism, administration, economics, urban and regional demography, political science, education, and geography; Life Sciences, which covers areas such as biological sciences, medicine, and public health; and exact, technological, and multidisciplinary sciences, which covers areas such as engineering, environmental sciences, geosciences, statistics, and chemistry.

To identify how the drivers relate, we use Exploratory Factor Analysis. We assessed the adequacy of the data for factor analysis using Bartlett's test of sphericity and Kaiser-Meyer-Olkin Measure of Sampling Adequacy (KMO) and extracted the factors using the principal component method.

The KMO index $(\mathrm{KMO}=0.89)$ and Bartlett's test of sphericity $(2604.76$, degrees of freedom $=190$, $p<0.0001)$ confirmed the validity of the factor analysis for the chosen variables. To define the number of factors, we considered the eigenvalues, the total variance explained, and the variance explained by each factor. For the analysis of each factor's internal consistency (reliability), we used Cronbach's alpha, whose value greater than 0.6 confirmed the consistency of all factors.

We performed several simulations to decide the set of factors most appropriate to reality, considering mainly aspects related to the correlation matrix, commonality, convergence between 
the screen plot, and the Kaiser criterion (eigenvalue more significant than one unit), and the results provided by Varimax rotation method. The best solution was to extract six factors that explain $72.3 \%$ of the total variance. We named according to their latent nature and the contextualized reality by the variables represented by each factor.

\section{Results and Discussion}

The main results achieved were the set of drivers identified from the bibliographic research and the survey's information synthesis.

\subsection{Selected Drivers}

Twenty drivers for improving the urban sanitary sewage system's intelligence were selected according to the criteria described in materials and methods (Table 1).

Table 1. Drivers for increasing the intelligence of urban sanitary sewage systems.

\begin{tabular}{|c|c|}
\hline Driver & Source \\
\hline $\begin{array}{l}\text { Environmental management: Actions based on environmental } \\
\text { management instruments (such as licensing and environmental impact } \\
\text { study) to eliminate/reduce possible impacts on the environment from } \\
\text { the sanitary sewer system's construction and operation. }\end{array}$ & {$[1,7,8,12-15,19-36]$} \\
\hline $\begin{array}{l}\text { Urban environment: Space with high population concentration and, } \\
\text { therefore, increased generation of effluents, which may have residential, } \\
\text { industrial, and commercial characteristics. }\end{array}$ & {$[1,7,12,14,22,33,35,37-39]$} \\
\hline $\begin{array}{l}\text { Environmental Sustainability Guidelines: Guidelines that guarantee the } \\
\text { safety and maintenance of natural resources, particularly water bodies } \\
\text { that receive wastewater. }\end{array}$ & {$[1,6,13,22,23]$} \\
\hline $\begin{array}{l}\text { Financing: Financing of works for the implantation or expansion of } \\
\text { sewage treatment and collection systems. }\end{array}$ & {$[6,21,33]$} \\
\hline $\begin{array}{l}\text { Investment: Application of financial resources in works to implement or } \\
\text { expand treatment and sewage collection systems. }\end{array}$ & {$[1,6,12,19,21,26,32,33,35,39-44]$} \\
\hline $\begin{array}{l}\text { Cost reduction and savings: Reduction in the operational cost of sewage } \\
\text { collection and treatment systems and the cost of implementation, } \\
\text { improvement, and system expansion. }\end{array}$ & $\begin{array}{c}{[1,6,12,19,21,26,32,33,35,39,40,} \\
42-44]\end{array}$ \\
\hline $\begin{array}{l}\text { Economic Sustainability Guidelines: Guidelines that guarantee the } \\
\text { financial security of sewage ventures during their execution and } \\
\text { operation. }\end{array}$ & {$[1,26,45]$} \\
\hline $\begin{array}{l}\text { Regulatory instruments: Decrees, master plans, and other legal } \\
\text { instruments that establish public order rules related to the } \\
\text { implementation, improvement, and expansion of sewage collection and } \\
\text { treatment systems. }\end{array}$ & {$[1,6,8,11,26,32,39,46,47]$} \\
\hline
\end{tabular}


Table 1. Cont.

\begin{tabular}{|c|c|}
\hline Driver & Source \\
\hline $\begin{array}{l}\text { Management structure: Institutional arrangements and allocation of } \\
\text { roles and responsibilities among interested parties for the sewage } \\
\text { system's management and operation. }\end{array}$ & {$[1,6,8,26,32,33,39,43]$} \\
\hline $\begin{array}{l}\text { Public policy: Government actions and decisions and state programs } \\
\text { that encourage and allocate funds for sewage projects. }\end{array}$ & $\begin{array}{l}{[6-8,11,14,15,19-22,26,32-34} \\
38-40,45,47-49]\end{array}$ \\
\hline $\begin{array}{l}\text { Professional qualification: Trained personnel with sufficient technical } \\
\text { knowledge to conduct sewage projects. }\end{array}$ & {$[13,26,33]$} \\
\hline $\begin{array}{l}\text { Integrated sustainability guidelines: Holistic guidelines aim to improve } \\
\text { sanitary sewer enterprise or service, understanding the relations } \\
\text { between economy, society, and environment. }\end{array}$ & {$[2,13,33]$} \\
\hline $\begin{array}{l}\text { System expansion: New works, implementation, and complementation } \\
\text { to expand the coverage area of the wastewater system. }\end{array}$ & {$[7,21,26,32,33,35]$} \\
\hline $\begin{array}{l}\text { Functionality: Ability of the sanitary sewage system to adequately fulfill } \\
\text { its function of capturing, conducting, treating, and discharging } \\
\text { wastewater in water bodies. }\end{array}$ & {$[1,7,13,35,49]$} \\
\hline Infrastructure: Sanitary sewage systems in urban areas. & $\begin{array}{c}{[1,7,12,19-21,26,29,31,33,35-37,} \\
39,41,50,51]\end{array}$ \\
\hline $\begin{array}{l}\text { Technical solutions: Creativity of designers searching for the best } \\
\text { technical solution considering cost, society, and environment. }\end{array}$ & $\begin{array}{c}{[1,6,7,12,13,19,23,26,29,30,33-} \\
35,38,41,43,51-54]\end{array}$ \\
\hline $\begin{array}{l}\text { Innovative technologies: Research, development, and application of new } \\
\text { technologies to solve or minimize problems related to sanitary sewage. }\end{array}$ & $\begin{array}{l}{[1,2,6,13,19,23,25-27,31-33,36} \\
37,42,52-58]\end{array}$ \\
\hline $\begin{array}{l}\text { Behavioral aspects of the population: Relationship of the population } \\
\text { with the sewage system to understand its benefits and the losses of its } \\
\text { misuse, such as the dumping of materials in the system. }\end{array}$ & $\begin{array}{c}{[1,6,14,19-21,24,26,32,35,36,39} \\
40,59]\end{array}$ \\
\hline $\begin{array}{l}\text { Population dynamics: Size and population growth rates of a given } \\
\text { region of the city. }\end{array}$ & {$[1,12,21,30,32,33,46]$} \\
\hline $\begin{array}{l}\text { Education: Awareness campaigns and programs aimed at the proper } \\
\text { use of the sewage system. }\end{array}$ & {$[1,12,14,33]$} \\
\hline
\end{tabular}

\subsection{Survey Results}

Initially, we calculated Cronbach's Alpha, whose value of 0.924 confirmed the reliability of the data. Then, we used the demographic data from the first section of the questionnaire to identify the interviewees' profile, considering their school of knowledge, their professional experience, and their academic qualification (Figure 3).

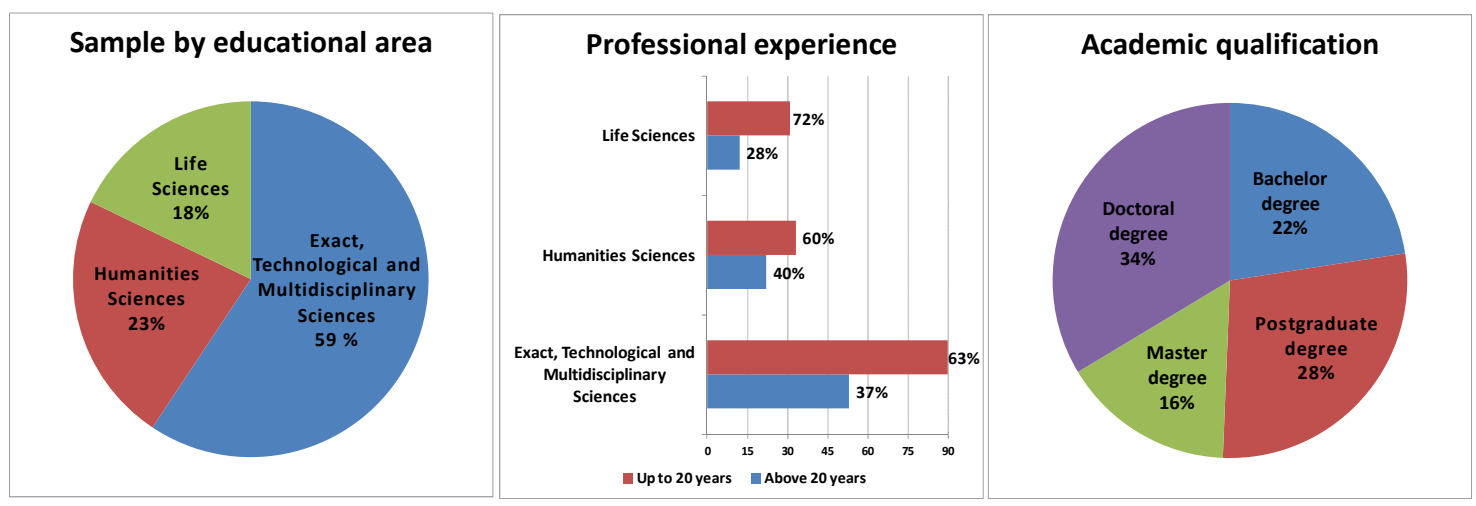

Figure 3. Interviewees' profile 
Figure 4 shows the drivers classified by the relative median for the three colleges of knowledge and the entire sample. All drivers were considered important by the specialists (the relative medians were greater than 3.0), corroborating the view of the researchers who publish on the subject.
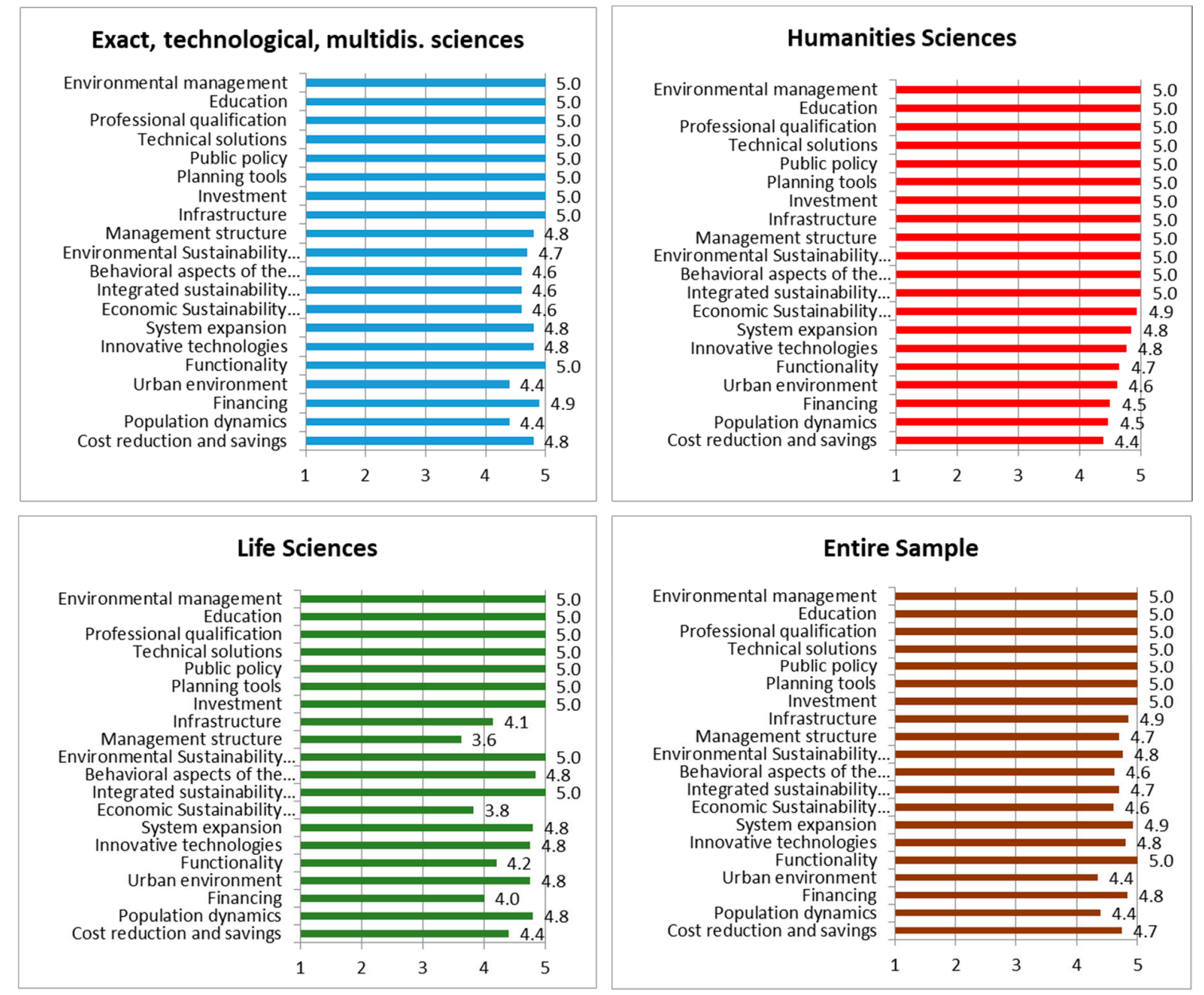

Figure 4. Drivers classified by the relative median for the three colleges of knowledge and total respondents.

Table 2 presents the drivers classified by the specialists as "extremely important" (equal to 5) in the three colleges of knowledge, of which seven drivers were considered "extremely important" for the three colleges and the entire sample. These drivers were considered a priority. Three drivers (environmental sustainability guidelines, integrated sustainability guidelines, and infrastructure) received the maximum rating in two colleges. Another three drivers (behavioral aspects of the population, system expansion, and functionality) received the top rating in only one college of knowledge. 
Table 2. Drivers ranked as "extremely important" by professionals who participated in the survey.

\begin{tabular}{lcccc}
\hline \multicolumn{1}{c}{ Guidelines } & $\begin{array}{c}\text { Exact, Technological, } \\
\text { Multidisciplinary Sciences }\end{array}$ & $\begin{array}{c}\text { Humanities } \\
\text { Sciences }\end{array}$ & $\begin{array}{c}\text { Life } \\
\text { Sciences }\end{array}$ & $\begin{array}{c}\text { Entire } \\
\text { Sample }\end{array}$ \\
\hline Investment & 5 & 5 & 5 & 5 \\
Regulatory instruments & 5 & 5 & 5 & 5 \\
Public policy & 5 & 5 & 5 & 5 \\
Technical solutions & 5 & 5 & 5 & 5 \\
Professional qualification & 5 & 5 & 5 & 5 \\
Education & 5 & 5 & 5 & 5 \\
Environmental management & 5 & 5 & 5 & 5 \\
Integrated sustainability guidelines & - & 5 & 5 & \\
Environmental Sustainability guidelines & - & 5 & 5 & \\
Infrastructure & 5 & 5 & - & \\
Functionality & 5 & - & - & 5 \\
Behavioral aspects of the population & - & 5 & - & - \\
System expansion & - & - & 5 & - \\
\hline
\end{tabular}

In Figure 4, seven drivers, which showed variations between the relative medians 4.01 and 4.99, are considered important, but with secondary priority: Management structure, System expansion, Population dynamics, Financing, Innovative Technologies, Urban environment, Cost reduction, and savings.

Figure 5 shows the driver's behavior when colleges of knowledge evaluations are compared with each other and with the entire sample.

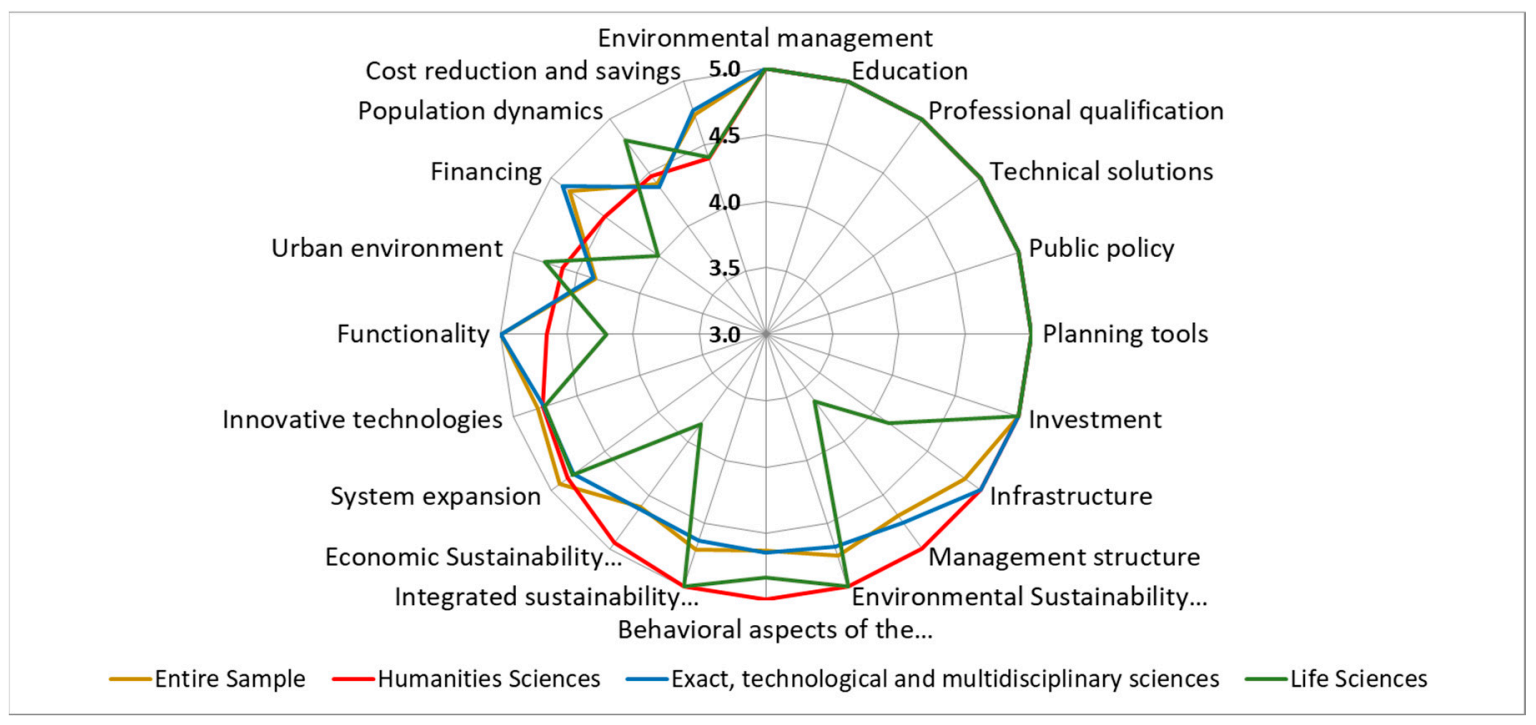

Figure 5. Driver's behavior for each school of knowledge and the entire sample.

Regarding the relationship between the drivers, the factor analysis grouped the drivers into six factors. Table 3 presents the drivers grouped by these factors, named according to their approach, and the respective factor loads. 
Table 3. Drivers grouped and named according to the aspect of the reality represented by each one.

\begin{tabular}{clc}
\hline Approach & \multicolumn{1}{c}{ Drivers } & Factor Loading \\
\hline \multirow{3}{*}{ Project sustainability } & Integrated sustainability guidelines & 0.85 \\
& Environmental Sustainability & 0.87 \\
& Guidelines & 0.69 \\
& Economic Sustainability Guidelines & 0.58 \\
& Environmental management & 0.59 \\
& Urban environment & 0.57 \\
& Population dynamics & 0.70 \\
Sewage system design & Infrastructure & 0.64 \\
& Functionality & 0.60 \\
\hline \multirow{2}{*}{ Sociocultural } & System expansion & 0.81 \\
& Behavioral aspects of the population & 0.72 \\
\hline \multirow{3}{*}{ Political-economic viability } & Education & 0.64 \\
& Financing & 0.83 \\
& Investment & 0.51 \\
& Regulatory instruments & 0.62 \\
\hline \multirow{2}{*}{ Technical quality } & Public policy & 0.73 \\
& Technical solutions & 0.80 \\
& Innovative technologies & 0.67 \\
\hline \multirow{2}{*}{ Economic and management } & Professional qualification & 0.72 \\
effectiveness & Cost reduction and savings & 0.66 \\
\hline & Management structure &
\end{tabular}

Table 4 shows that the approach related to political-economic viability contains the highest number of priority drivers, which can be considered the most relevant from the experts' perspective, followed by the technical quality approach, with two priority drivers and sociocultural and project sustainability with a driver each. Drivers related to sewage system design and economic and management effectiveness approaches were not considered a priority.

Table 4. Priority drivers grouped by the approach.

\begin{tabular}{cc}
\hline Approach & Priority Driver \\
\hline Project sustainability & Environmental management \\
Sewage system design & - \\
Sociocultural & Education \\
Political-economic viability & Investment, Regulatory instruments, Public policy \\
Technical quality & Professional qualification, Technical solutions \\
Economic and management effectiveness & - \\
\hline
\end{tabular}

In the project sustainability approach, drivers meet holistic and integrative approaches present in the literature, mainly covering the relations between economy, society, and the environment. Thus, the sanitation system must be economically viable, socially just, and technically adequate and also protect the environment and natural resources [60].

Some authors have approached project sustainability with an emphasis on a specific dimension of sustainability. Concerning the environmental aspect, the main focus has been on ensuring water bodies' safety and maintenance that receive wastewater and contamination of the subsoil [1,25]. Regarding the economic aspect, the aspects related to the enterprise's viability and financial security during its execution and operation have aroused greater interest [1]. The social aspect has been addressed mainly considering the impacts on the community's health and safety [28] and the participation of society [14]. Considering that technical solutions are those that, in practice, incorporate aspects of sustainability in the built infrastructure, several studies have also been developed with this 
objective [2,13], including addressing the professional aspects [43], since sustainability, it has been a transversal theme to the areas of knowledge and increasingly present in professional activities.

In this approach, the Environmental management driver was considered a priority by the specialists. Environmental management's main objective is to minimize environmental impacts throughout the life cycle of urban sanitary sewage systems. It is mainly related to the structuring and operationalization of institutional arrangements that will be put in place for environmental management, such as, for example, ministries, agencies, committees, and municipal secretariats. Thus, environmental management's success is intrinsically related to the effectiveness of institutional arrangements [61].

Regarding the Sewage system design approach, the drivers relate to the strategic variables of the system design. The urban environment is a space with a high population concentration and, therefore, with a high effluent generation. The proper understanding of the characteristics of the different regions of the urban space, such as being residential, industrial, and commercial, has a great influence on the system's success. However, the literature shows that the sewage system design must go beyond the urban environment characteristics. The sewage system's success is also strongly influenced by Population dynamics. The population's size and growth rates in the city's regions influence its population concentration dynamics and, consequently, the volume of effluents generated. In this context, an intelligent system must be able to monitor whether the existing infrastructure adequately fulfills its function of capturing, conducting, treating, and discharging wastewater in water bodies depending of effluents volume generated, and proposing solutions for improving the existing infrastructure or expanding the coverage area, who have the flexibility to deal with variations in demand and who use the most appropriate technologies.

Another important point is that the rapid population growth experienced by several urban centers in Brazil and other developing countries has caused a disorderly expansion of cities. In several Latin American countries, including Brazil, occupations and land use formalized by government plans and actions and informal urban conditions, such as favelas and peripheries [16], coexist. These countries' health infrastructure has not been able to keep up with this expansion, especially in informal urban areas [1]. In this scenario, the increase of sewage system intelligence is highly dependent on solving structural problems.

Although sewage system planning enhances the management of services and benefits the population by reducing improvisations and emergency decisions and directing medium and long-term actions, no driver of this approach was considered a priority by experts.

Concerning the sociocultural approach, the main driver's focus is the behavioral aspects of the population, mainly about the population relationship with the sewage system, and education to raise awareness and provide information. The population's behavior is influenced by several factors, such as social, demographic, cultural, political, economic, administrative, and educational [62], which shape how the population interacts with the system and understands its benefits and the losses of its bad utilization.

In this approach, Driver Education was considered a priority by specialists. It is mainly related to actions that increase the population's understanding of the best way to interact with the system, such as, for example, awareness campaigns and programs. It is important that consumers mainly from developing and developed countries are educated about the risks, available options, and associated costs for the sustainable sanitation systems provision [63], since the lack of knowledge and consumer participation can go beyond association normally done between sanitation and health and also cover the lack of understanding about how the systems operate [64]. Thus, the attachment to the system and care for it, due to its relationship with the quality of life, will be greater, which increases the possibility of the system success [1,24].

In the political-economic viability approach, drivers focus on public policy, regulatory instruments, financing, and investment. Adequate public policy drives the primary sanitation sector. Consequently, wastewater systems $[26,39]$, leveraging government actions and decisions and state programs that 
encourage and allocate funds for sanitation sewerage projects, thus enabling the improvement and expansion of these systems $[7,33,39]$. They regulate the system financing and direct incentives and legal and financial guarantees for investments [40].

Public policies related to sanitary sewage have been mainly aimed at solving structural problems and improving system performance and results quality, not following the same objectives adopted for the policies formulation of other services of smart cities ecosystem. We envision two factors that can help to understand this context. The first is that the development of new technologies and the applicability and versatility of their use have been more intense for other smart cities' ecosystem components, such as smart mobility and smart buildings, which encourages the demand from manufacturers and users for more appropriate policies. The second is that the results visibility of actions aimed at increasing these components intelligence is more noticeable and immediate. However, in more evolved systems, policies are translated into laws and regulations that make them less susceptible to governments' political conveniences [6,11,15,39,49].

In addition to public policy, the regulatory instrument driver was also considered a priority by specialists. These are formed mainly by legislation, technical standards, and recommendations from the agencies responsible for approving and monitoring the project. They provide a more stable environment for public and private investments and guarantee users' rights with respect to the obligations to provide the service and the sustainability and stability of these services. In general, smart city systems demand less bureaucratic, expensive, and rigid rules and regulations that hinder innovation and competitiveness. In the case of sewage systems, regulatory instruments must focus on what is most fundamental and urgent for increasing the sector's intelligence.

In this sense, the development of norms that establish guidelines and rules for the use of new technologies and the interoperability of systems and devices, and specific legislation that improves society's participation process should be a priority. It is important to note that the development of new technologies brought about by technological innovations is still incipient in Brazil. In this context, it is essential to create a regulatory framework that enhances the innovation environment, and that adheres to the main innovation management standards (ISO 56000: 2020-Fundamentals and vocabulary; ISO 56002: 2019-Innovation management system-Guidance; ISO 56003: 2019-Tools and methods for innovation partnership-Guidance; ISO 56004: 2019-Innovation Management Assessment-Guidance)

Concerning investments in sewage infrastructure, smarter systems demand smarter processes and the incorporation of new technologies, which increases the volume of investments required. In many countries, government institutions are the main sponsors of the implementation, modernization, and expansion of sewage systems. However, investments have been insufficient, mainly in underdeveloped and developing countries, due to the low investment power resulting from fragile economies [33,35], the high cost of works and the operation of the system [19,21], and the election of other infrastructure sectors as priorities, such as, for example, water supply [32,37]. In this context, the smart combination of financing instruments and financing commitments minimizes credit crises and improves the planning of infrastructure project/investment [65].

Technical quality approaches are strongly associated with the typology and technical feasibility of solutions and their influence on cost, society, and the environment. The experts showed that technical solutions, professional qualification, and the incorporation of innovative technologies are the most relevant aspects of improving the intelligence of the sewage system, the first two being considered priorities.

Regarding technical solutions, the concept of "appropriate technology" is often used to represent the context in which solutions must be developed. Thus, the appropriate technology is one that enables safe and efficient sanitary conditions that make the construction, operational, and cost aspects compatible with the socioeconomic, environmental, and cultural characteristics of the communities [66]. In Brazilian legislation [67], appropriate technology takes on motivating the gradual and progressive adoption of solutions that take into account local peculiarities and the ability to pay for services by 
the population. Thus, technical solutions focus beyond the narrow sense of technical engineering design, which aims to meet technical standards. This context makes the increase of the system demand intelligence an interdisciplinary professional qualification, which must increasingly emphasize the ability to identify and understand the political, social, and cultural dimensions and make them compatible with the alternatives and technological innovations, to that solutions are more adherent to local realities.

Thus, the increase in system intelligence is also intrinsically related to the ability to incorporate technologies that enable new solutions or to improve the performance of existing solutions. An intelligent sewage system must be thought of as one of the components of the complex ecosystem of smart cities. Thus, integrating the sewage system with smart systems will provide a more intelligent urban system by allowing intelligent decisions at both levels.

Although the fast pace with which new technologies are developed enhances the increased acceleration of sewage systems intelligence, the pace of their incorporation differs between countries, depending on their culture, strategies, and objectives. In underdeveloped and developing countries, the incorporation of new technologies has been conservative. Thus, some barriers that hinder changes in current technological standards are the technicist approach, the dissociation between technique and politics, the resistance to dialogue between theory and practice, the reductionist performance where one does not seek to understand reality in its complexity, the consideration of technical knowledge as superior, the inability to dialogue, the supremacy of projects with conventional conceptions, and the excessive focus on economic viability [68].

Regarding the economic and management effectiveness approach, the main driver's focus is the aspects related to cost reduction and savings and management structure. In the literature consulted, cost reduction focuses on the implementation costs related to the design, construction, and improvement of the collection and treatment systems and operational costs. In the context of savings, the incorporation of new technologies demanded by more intelligent systems plays a fundamental role.

In the design phase, new computational methods collaborate for the optimization of essential variables, such as, for example, the excavation volume, shoring structure, extension of pipes, and criteria for the selection of sewage treatment alternatives.

In the construction phase, in addition to the costs inherent to the construction process, the costs arising from impacts to the environment must also be considered. Conventional trenching processes, installation of pipes and components, and pavement replacement have a strong impact on residents, traffic, and economic activities. In this context, new technologies for excavation, compaction, and pavement replacement can also collaborate to reduce costs and impacts.

In the operating phase, savings should focus mainly on spending on the resources used (energy and other public services, materials, labor, and equipment). Sewage system characteristics, such as networks and components located in the subsoil, make it challenging to check maintenance and operation conditions [69], which increases costs. Considering that planned maintenance is much more economical in the long and short term [70], the use of new technologies, such as sensors and intelligent maintenance management systems, can collaborate to reduce these costs.

Concerning the driver management structure, the main focus is on institutional arrangements and the allocation of roles and responsibilities among stakeholders to manage and operate the sewage system. A more current and comprehensive way of understanding a smart city is that of an innovative city, which combines aspects of intelligence and sustainability through governance that integrates the interactions of interested parties [23,71]. As a driver of the smart city, the sewage system must also consider the complexities of these interactions. There must be a concentrated and cooperative effort among stakeholders, including owners, municipal officials, and local agencies [70]. The actions demanded by the roles and each stakeholder's responsibilities can converge towards increasing the system's intelligence.

Considering that this work's results have a different bias from other studies on smart cities and their systems, some aspects must be contextualized. Although discussions about smart cities are 
not recent, researchers, institutions, and governments' approaches show no consensus on what a smart city is. In these approaches, there is a massive presence of studies related to innovation and new technologies incorporation, mainly information and communication technologies (ICTs), aiming to improve sustainability, interactivity with the user, the population participation in decision-making processes, and other city issues' service management in a context of challenges. The increase in cities' intelligence has been a challenge experienced to a greater or lesser extent by city managers.

The concept of a smart city has evolved mainly due to the reality of cities in developed countries. However, these countries' urban systems have gone through stages of evolution that have not yet occurred in underdeveloped and developing countries to a greater or lesser extent. The challenges imposed by this reality have influenced studies relating the term intelligence to the sewage system. Approximately $85 \%$ of the articles identified in the bibliographic research are focused on the sanitary sewage system in underdeveloped and developing countries, which makes the identified drivers present this profile. The survey results also corroborated with the authors' understanding since all drivers were considered very important.

Another important aspect is that a significant portion of the drivers associated with smart cities is also important for "traditional" cities. For example, the public policies driver is present in most works related to city management, whether they are smart or not. Other drivers identified in this work, such as, for example, regulatory instruments, innovative technologies, sustainability guidelines, and population behavioral, have also been considered important for city systems, whether they are intelligent or not. In addition, these drivers have also been considered important in studies aimed at increasing the intelligence of other systems in the city, such as, for example, smart mobility and smart grids. However, drivers like Professional Qualification and System Expansion are more specific to exhaust systems.

Why have some systems received more attention than others? We highlight two factors that seem to influence this situation. The first is that the benefits of increasing the intelligence of some systems provide in the population's daily life are more noticeable. The second is that incorporating new solutions, especially technological ones, is more straightforward and more immediate for some of these systems due to their characteristics. It makes the Water Environment Federation's [72] finding that "intelligent water systems are still in its infancy" also a reality for sewage systems.

This context must also be associated with the fact that every driver has a challenge component due to its current reality transformation objective. The size of this challenge is a function of the reality to be changed, which, for the city's systems, is also influenced by the system's intrinsic characteristics and the attractiveness of the results provided by the increase of its intelligence. It makes the reality of each country significantly influence the way the drivers are interpreted. Thus, concerning the scope of this study's results, we believe that the perception of the problems inherent to the cities' reality in each country can influence the degree of importance attributed to the set of drivers. However, the Brazilian reality is similar to that of many countries. It means that aspects of this reality are experienced to a greater or lesser extent by most cities in underdeveloped and developing countries.

Usually, the drivers associated with smart cities are numerous due to the many variables involved and the different views of interested parties. In this sense, the results confirmed this expectation due to the bibliographic research's rigorous procedures. However, there is always the possibility that some relevant article has not been considered.

All drivers were considered important by the professionals who participated in the survey, corroborating the authors' view who work with the theme. However, it is important to note that all research based on experts' judgment has some degree of subjectivity resulting from the evaluator's interpretation of what is being evaluated. The most recommended is that all the drivers considered important are the focus of the managers' actions. However, in a scarcity of resources, the most priority must be selected so that governments, managers, and investors can prioritize their efforts.

The prioritization strategy adopted was: a) group the survey results considering the three colleges of knowledge organized by the Coordination for the Improvement of Higher Education Personnel 
(CAPES), Brazil, which group the training areas according to their affinity objects, cognitive methods, and instrumental resources; $b$ ) consider drivers with a median equal to five as a priority in the three colleges of knowledge: there is unanimity regarding their importance. This way of evaluating the results according to each College's professionals' vision made the results more adherent to the reality experienced by Brazilian cities.

Finally, we can conclude that Brazilian cities' reality means that increasing the intelligence of sewage systems has to consider earlier stages, in which inefficiencies and structural problems are present.

\section{Conclusions}

In a context of increasing incorporation of the concept of smart city, urban sanitary sewage systems should be considered integrated to this context since the increase in the cities intelligence occurs mainly due to the increase in their systems' intelligence. In the literature, few studies aimed at identifying drivers that influence the increase in the urban sanitary sewage system intelligence. It was the focus of this work, researching the drivers that increase this system's intelligence, grouping them according to their approaches, and identifying the most priority.

The survey results showed that due to the drivers' relationship, they could be grouped into six approaches: Project sustainability, sewage system design, sociocultural, political-economic viability, technical quality, economic and management effectiveness. It also showed that of the twenty drivers found in the literature, seven could be considered a priority: Public policy, regulatory instruments, investment, environmental management, education, professional qualification, and technical solutions, and that the drivers of the Sewage system design and economic and management effectiveness approaches were not considered a priority.

Concerning policymakers, the results show the importance of public policy and regulatory instruments for increasing the system's intelligence. From the perspective of priority drivers, we expect policymakers to create an environment in which guidelines and rules make the investment in the sector more attractive and increase the ability to incorporate technologies that enable new solutions and improve existing ones performance. Another important action is the improvement of professional qualifications. A smart sewage system requires an interdisciplinary professional qualification, which must emphasize the ability to identify and understand the political, social, and cultural dimensions and make them compatible with technological alternatives and innovations to be more adherent to local realities. We also expect a greater emphasis on creating tools that improve the population's understanding of how best to interact with the system.

Concerning investors, the investment driver signals the importance of their role. Smarter sewage systems demand more intelligent processes and the incorporation of new technologies, which increases the demand for more investments. However, the system's increased intelligence enhances the improvement of its performance, which makes investment in the sector more attractive. In this context, the smart combination of public and private financing instruments can minimize credit crises.

Concerning public and private managers, their performance is directly related to the system's management and operation, which are the main means of generating cost and performance indicators. In addition, its performance is also strongly influenced by public policy, regulatory instruments, and available resources. In this context, they can play a fundamental role as an interface between policymakers and investors, providing indicators that collaborate to improve each's decision-making process, such as those related to environmental management, education, professional qualification, and technical solutions. It is important to note that the path to smarter sewage systems is highly dependent on accurate diagnoses of the current situation.

Considering the scarcity of resources experienced by many countries, we hope that the results of this work can collaborate so that governments, managers, and investors can prioritize their efforts. 
Author Contributions: Conceptualization, survey, data curation, methodology, writing-original draft, formal analysis, writing - review and editing, R.G.d.A. and C.A.P.S.; visualization, writing — review and editing, C.K.C., M.C.P.G.d.A., F.C.D., R.L.V.M., and O.C.L.; supervision, C.A.P.S. All authors have read and agreed to the published version of the manuscript.

Funding: This research received no external funding.

Acknowledgments: The authors would like to thank all the experts who answered the survey. The authors also express their gratitude to the editor and anonymous reviewers for comments and suggestions.

Conflicts of Interest: The authors declare no conflict of interest.

\section{References}

1. Nansubuga, I.; Banadda, N.; Verstraete, W.; Rabaey, K. A review of sustainable sanitation systems in Africa. Rev. Environ. Sci. Bio/Technol. 2016, 15, 465-478. [CrossRef]

2. Du, J.; Kuang, B.; Yang, Y. A Data-Driven Framework for Smart Urban Domestic Wastewater: A Sustainability Perspective. Adv. Civ. Eng. 2019, 2019, 1-15. [CrossRef]

3. Tang, L.; Li, K.; Jia, P. Impact of Environmental Regulations on Environmental Quality and Public Health in China: Empirical Analysis with Panel Data Approach. Sustainability 2020, 12, 623. [CrossRef]

4. Afifi, S.; Alnahhal, S.; AbdelAll, S. Developing an Integrated Sustainable Sanitation System for Urban Areas: Gaza Strip Case study. Procedia CIRP 2015, 26, 767-774. [CrossRef]

5. Heller, L.; De Albuquerque, C.; Roaf, V.; Jiménez, A. Overview of 12 Years of Special Rapporteurs on the Human Rights to Water and Sanitation: Looking Forward to Future Challenges. Water 2020, 12, 2598. [CrossRef]

6. Kiparsky, M.; Thompson, J.B.H.; Binz, C.; Sedlak, D.L.; Tummers, L.; Truffer, B. Barriers to Innovation in Urban Wastewater Utilities: Attitudes of Managers in California. Environ. Manag. 2016, 57, 1204-1216. [CrossRef] [PubMed]

7. Goncalves, M.L.R.; Kleidorfer, M.; Rauch, W. Case study on the use of a combined system as an intermediate solution in Brazil: Cost estimate. Water Environ. J. 2017, 31, 478-485. [CrossRef]

8. Mena-Rivera, L.; Vásquez-Bolaños, O.; Gómez-Castro, C.; Fonseca-Sánchez, A.; Rodríguez-Rodríguez, A.; Sánchez-Gutiérrez, R. Ecosystemic Assessment of Surface Water Quality in the Virilla River: Towards Sanitation Processes in Costa Rica. Water 2018, 10, 845. [CrossRef]

9. Froufe, M.M.; Chinelli, C.K.; Guedes, A.L.A.; Haddad, A.; Hammad, A.W.A.; Soares, C.A.P. Smart Buildings: Systems and Drivers. Build. 2020, 10, 153. [CrossRef]

10. Guedes, A.L.A.; Alvarenga, J.C.; Goulart, M.D.S.S.; Rodriguez, M.V.R.Y.; Soares, C.A.P. Smart Cities: The Main Drivers for Increasing the Intelligence of Cities. Sustainability 2018, 10, 3121. [CrossRef]

11. Gonçalves, M.B.V.B. Privatização Da Cedae: Na Contramão Do Movimento Mundial De Remunicipalização Dos Serviços De Saneamento/Privatization of Cedae: Opposite to the Global Trend of Sanitation Services Remunicipalization. Geo UERJ 2017, 31, 100-101. [CrossRef]

12. De Troyer, N.; Mereta, S.T.; Goethals, P.; Boets, P. Water Quality Assessment of Streams and Wetlands in a Fast Growing East African City. Water 2016, 8, 123. [CrossRef]

13. Chen, X.; Xu, Z.; Yao, L.; Ma, N. Processing Technology Selection for Municipal Sewage Treatment Based on a Multi-Objective Decision Model under Uncertainty. Int. J. Environ. Res. Public Health 2018, 15, 448. [CrossRef] [PubMed]

14. França, J.S.; Solar, R.; Hughes, R.M.; Callisto, M. Student monitoring of the ecological quality of neotropical urban streams. AMBIO 2019, 48, 867-878. [CrossRef]

15. Morris, L.; Colombo, V.; Hassell, K.; Kellar, C.; Leahy, P.; Long, S.M.; Myers, J.H.; Pettigrove, V. Municipal wastewater effluent licensing: A global perspective and recommendations for best practice. Sci. Total. Environ. 2017, 580, 1327-1339. [CrossRef]

16. Lima, E.G.; Chinelli, C.K.; Guedes, A.L.A.; Vazquez, E.G.; Hammad, A.W.A.; Haddad, A.; Soares, C.A.P. Smart and Sustainable Cities: The Main Guidelines of City Statute for Increasing the Intelligence of Brazilian Cities. Sustainability 2020, 12, 1025. [CrossRef]

17. Alvarenga, J.C.; Branco, R.R.; Guedes, A.L.A.; Soares, C.A.P.; Da Silva, W.S. The project manager core competencies to project success. Int. J. Manag. Proj. Bus. 2019, 13, 277-292. [CrossRef] 
18. Alvarenga, J.C.; Branco, R.R.; Valle, A.B.; Soares, C.A.P.; Silva, W.S.E. The self-perception of project managers compared to other project actors. Interciencia 2019, 44, 444-453.

19. Koop, S.H.A.; Van Leeuwen, K. The challenges of water, waste and climate change in cities. Environ. Dev. Sustainability 2017, 19, 385-418. [CrossRef]

20. Rodrigues, V.F.; Rivera, I.N.; Lim, K.-Y.; Jiang, S.C. Detection and risk assessment of diarrheagenic E. coli in recreational beaches of Brazil. Mar. Pollut. Bull. 2016, 109, 163-170. [CrossRef]

21. Rahm, B.G.; Vedachalam, S.; Shen, J.; Woodbury, P.B.; Riha, S.J. A watershed-scale goals approach to assessing and funding wastewater infrastructure. J. Environ. Manag. 2013, 129, 124-133. [CrossRef] [PubMed]

22. Jacobi, P.R.; Sánchez, S.S.; Fracalanza, A.P. Gobernanza del agua en la ciudad de sao paulo: Actores sociales, degradacion socioambiental y acciones publicas innovadoras. Am. Lat. Hoy 2015, 69, 36-48.

23. Martínez, R.; Vela, N.; El Aatik, A.; Murray, E.; Roche, P.; Navarro, J.M. On the Use of an IoT Integrated System for Water Quality Monitoring and Management in Wastewater Treatment Plants. Water 2020, 12, 1096. [CrossRef]

24. Panasiuk, O.; Hedström, A.; Marsalek, J.; Ashley, R.M.; Viklander, M. Contamination of stormwater by wastewater: A review of detection methods. J. Environ. Manag. 2015, 152, 241-250. [CrossRef]

25. Sempere-Payá, V.; Santonja-Climent, S. Integrated sensor and management system for urban waste water networks and prevention of critical situations. Comput. Environ. Urban Syst. 2012, 36, 65-80. [CrossRef]

26. Reymond, P.; Wahaab, R.A.; Moussa, M.S.; Lüthi, C. Scaling up small scale wastewater treatment systems in low- and middle-income countries: An analysis of challenges and ways forward through the case of Egypt. Util. Policy 2018, 52, 13-21. [CrossRef]

27. Da Cunha, D.L.; De Paula, L.M.; Da Silva, S.M.C.; Bila, D.M.; Da Fonseca, E.M.; Oliveira, J.L.M. Occurrence of estrogens and their removal by biological processes of sewage treatment. Rev. Ambient. Agua 2017, 12, 257-258.

28. Whitehead, P.G.; Bussi, G.; Hossain, M.A.; Dolk, M.; Das, P.; Comber, S.; Peters, R.; Charles, K.J.; Hope, R.; Hossain, S. Restoring water quality in the polluted Turag-Tongi-Balu river system, Dhaka: Modelling nutrient and total coliform intervention strategies. Sci. Total. Environ. 2018, 631-632, 223-232. [CrossRef]

29. López-Morales, C.A.; Rodríguez-Tapia, L. On the economic analysis of wastewater treatment and reuse for designing strategies for water sustainability: Lessons from the Mexico Valley Basin. Resour. Conserv. Recycl. 2019, 140, 1-12. [CrossRef]

30. Dey, D.; Banerjee, S. Wastewater management and the east-bound growth of the city of Kolkata: A compatibility analysis. Environ. Dev. Sustain. 2016, 19, 1911-1932. [CrossRef]

31. Oladoja, N. Appropriate technology for domestic wastewater management in under-resourced regions of the world. Appl. Water Sci. 2017, 7, 3391-3406. [CrossRef]

32. Lwin, C.M.; Maung, K.N.; Hashimoto, S. Future sewage sludge generation and sewer pipeline extension in economically developing ASEAN countries. J. Mater. Cycles Waste Manag. 2015, 17, 290-302. [CrossRef]

33. Chirisa, I.; Bandauko, E.; Matamanda, A.; Mandisvika, G. Decentralized domestic wastewater systems in developing countries: The case study of Harare (Zimbabwe). Appl. Water Sci. 2017, 7, 1069-1078. [CrossRef]

34. Hernández-Chover, V.; Bellver-Domingo, Á.; Hernández-Sancho, F. Efficiency of wastewater treatment facilities: The influence of scale economies. J. Environ. Manag. 2018, 228, 77-84. [CrossRef] [PubMed]

35. Mendes, T.M.; Barcellos, C. The Territorial Dimension of Sewage Networks: The Case of Recreio dos Bandeirantes, Rio de Janeiro, Brazil. Cien Saude Colet 2018, 23, 647-658. [CrossRef] [PubMed]

36. Qu, X.; Alvarez, P.J.; Li, Q. Applications of nanotechnology in water and wastewater treatment. Water Res. 2013, 47, 3931-3946. [CrossRef]

37. Dano, U.L.; Balogun, A.-L.; Abubakar, I.R.; Aina, Y.A. Transformative urban governance: Confronting urbanization challenges with geospatial technologies in Lagos, Nigeria. Geo J. 2019, 85, 1039-1056. [CrossRef]

38. Goodspeed, R. Smart cities: Moving beyond urban cybernetics to tackle wicked problems: Figure 1. Camb. J. Reg. Econ. Soc. 2015, 8, 79-92. [CrossRef]

39. Estache, A.; Garsous, G.; Da Motta, R.S. Shared Mandates, Moral Hazard, and Political (Mis)alignment in a Decentralized Economy. World Dev. 2016, 83, 98-110. [CrossRef]

40. Arruda, P.N.; Lima, A.S.C.; Scalize, P.S. Gestão dos serviços públicos de água e esgoto operados por municípios em Goiás, GO, Brasil. Rev. Ambient. Agua 2016, 11, 371-374. 
41. Poortvliet, P.M.; Sanders, L.; Weijma, J.; De Vries, J.R. Acceptance of new sanitation: The role of end-users' pro-environmental personal norms and risk and benefit perceptions. Water Res. 2018, 131, 90-99. [CrossRef] [PubMed]

42. Fernández, F.G.A.; Gómez-Serrano, C.; Morales-Amaral, M.M.; Fernández-Sevilla, J.M.; Molina-Grima, E. Wastewater treatment using microalgae: How realistic a contribution might it be to significant urban wastewater treatment? Appl. Microbiol. Biotechnol. 2016, 100, 9013-9022. [CrossRef]

43. Molinos-Senante, M.; Gomez, T.L.; Caballero, R.; Hernandezsancho, F.; Sala-Garrido, R. Assessment of wastewater treatment alternatives for small communities: An analytic network process approach. Sci. Total. Environ. 2015, 532, 676-687. [CrossRef] [PubMed]

44. Lu, H.; Wang, J.; Wang, T.; Wang, N.; Bao, Y.; Hao, H. Crystallization techniques in wastewater treatment: An overview of applications. Chemosphere 2017, 173, 474-484. [CrossRef]

45. Gallego-Valero, L.; Moral-Pajares, E.; Román-Sánchez, I.M.; Pérez, J.S. Analysis of Environmental Taxes to Finance Wastewater Treatment in Spain: An Opportunity for Regeneration? Water 2018, 10, 226. [CrossRef]

46. Teklehaimanot, G.Z.; Kamika, I.; Coetzee, M.A.A.; Momba, M.N.B. Population Growth and Its Impact on the Design Capacity and Performance of the Wastewater Treatment Plants in Sedibeng and Soshanguve, South Africa. Environ. Manag. 2015, 56, 984-997. [CrossRef]

47. Jia, G.; Han, G.; Du, J.; Chan, S. PMS: Intelligent Pollution Monitoring System Based on the Industrial Internet of Things for a Healthier City. IEEE Netw. 2019, 33, 34-40. [CrossRef]

48. Brown, C.; Heller, L. Cooperación para el desarrollo en los sectores de agua y saneamiento: ¿está basada en el marco de los derechos humanos? Cien Saude Colet 2017, 22, 2248.

49. De Oliveira, T.G.; De Lima, S.C.R.B. The Privatization of State Water Supply and Sanitation Companies: An Analysis Based on the Experience of the State of Minas. Ambient. Soc. 2015, 18, 253-256.

50. Mattsson, J.; Hedström, A.; Ashley, R.; Viklander, M. Impacts and managerial implications for sewer systems due to recent changes to inputs in domestic wastewater-A review. J. Environ. Manag. 2015, 161, 188-197. [CrossRef]

51. Öberg, G.; Mason-Renton, S.A. On the limitation of evidence-based policy: Regulatory narratives and land application of biosolids/sewage sludge in BC, Canada and Sweden. Environ. Sci. Policy 2018, 84, 88-96. [CrossRef]

52. Kaushal, S.S.; McDowell, W.H.; Wollheim, W.M.; Johnson, T.A.N.; Mayer, P.M.; Belt, K.T.; Pennino, M.J. Urban Evolution: The Role of Water. Water 2015, 7, 4063-4087. [CrossRef]

53. Gasser, C.A.; Ammann, E.M.; Shahgaldian, P.; Corvini, P.F.-X. Laccases to take on the challenge of emerging organic contaminants in wastewater. Appl. Microbiol. Biotechnol. 2014, 98, 9931-9952. [CrossRef] [PubMed]

54. Zhu, W.; Wang, Z.; Zhang, Z. Renovation of Automation System Based on Industrial Internet of Things: A Case Study of a Sewage Treatment Plant. Sensors 2020, 20, 2175. [CrossRef]

55. Gu, B.; Fan, L.; Ying, Z.; Xu, Q.; Luo, W.; Ge, Y.; Scott, S.; Chang, J. Socioeconomic constraints on the technological choices in rural sewage treatment. Environ. Sci. Pollut. Res. 2016, 23, 20360-20367. [CrossRef]

56. Vialkova, E.; Zemlianova, M.A.; Vorotnikova, A.; Cherkashin, D.; Voronov, A.; Maksimov, L. The protection of urban areas from surface wastewater pollutions. MATEC Web Conf. 2017, 106, 7008. [CrossRef]

57. Farmanbar, M.; Parham, K.; Arild, Ø.; Rong, C. A Widespread Review of Smart Grids Towards Smart Cities. Energies 2019, 12, 4484. [CrossRef]

58. Abbas, O.; Rjeily, Y.A.; Sadek, M.; Shahrour, I. A large-scale experimentation of the smart sewage system. Water Environ. J. 2017, 31, 515-521. [CrossRef]

59. Cheng, S.; Li, Z.; Uddin, S.M.N.; Mang, H.P.; Zhou, X.; Zhang, J.; Zheng, L.; Zhang, L. Toilet revolution in China. J. Environ. Manag. 2018, 216, 347. [CrossRef]

60. Langergraber, G. Are constructed treatment wetlands sustainable sanitation solutions? Water Sci. Technol. 2013, 67, 2133-2140. [CrossRef]

61. Acheampong, P.T. Environmental Sanitation Management in the Kumasi Metropolitan Area. Master's Thesis, Kwame Nkrumah University of Science and Technology, Kumasi, Ghana, 2010.

62. Leme, S.M. Comportamento da população urbana no manejo dos resíduos sólidos. Geografia 2009, 18, 157-192.

63. Andersson, K.; Dickin, S.; Rosemarin, A. Towards "Sustainable" Sanitation: Challenges and Opportunities in Urban Areas. Sustainability 2016, 8, 1289. [CrossRef] 
64. Naughton, O.; Hynds, P. Public awareness, behaviours and attitudes towards domestic wastewater treatment systems in the Republic of Ireland. J. Hydrol. 2014, 518, 108-119. [CrossRef]

65. Wadhwa, M. Understanding the Impact of Smart Cities and the Need for Smart Regulations. SSRN Electron. J. 2015. [CrossRef]

66. Ennes, Y.M. O saneamento no Brasil, repassado à luz da tecnologia apropriada. Rev. Min. Eng. 1989, 3, 13-16.

67. BRASIL. Lei no 11.445, de 05 de Janeiro de 2007, Brasília. Available online: http://www.planalto.gov.br/ ccivil_03/_Ato2007-2010/2007/Lei/L11445.htm (accessed on 1 October 2020).

68. Borja, P.; Moraes, L.R. Paradigmas tecnológicos do saneamento básico no Brasil. In Engenharia Sanitária e Ambiental: Tecnologias para a Sustentabilidade 5; Atena: Ponta Grossa, Brasil, 2020; pp. 188-200. [CrossRef]

69. Junior, A.D.C.G.; Paganini, W.D.S. Aspectos conceituais da regulação dos serviços de água e esgoto no Brasil. Eng. Sanit. Ambient. 2009, 14, 79-88. [CrossRef]

70. NEIWPCC (New England Interstate Water Pollution Control Commission). Optimizing Operation, Maintenance, and Rehabilitation of Sanitary Sewer Collection Systems. 2003. Available online: https://www3.epa.gov/npdes/pubs/sso_optimizing_appa.pdf (accessed on 1 October 2020).

71. Metz, F.; Glaus, A. Integrated Water Resources Management and Policy Integration: Lessons from 169 Years of Flood Policies in Switzerland. Water 2019, 11, 1173. [CrossRef]

72. Water Environment Federation. Intelligent Water Systems: The Path to a Smart Utility, 2017. Available online: http://ir.knust.edu.gh/xmlui/handle/123456789/173. (accessed on 31 May 2020).

Publisher's Note: MDPI stays neutral with regard to jurisdictional claims in published maps and institutional affiliations. 